\title{
Challenges of Mentoring Among University Academics in Nigeria
}

\section{Enaruna Ehimwenma IDUBOR, Simon Ayo ADEKUNLE*}

Department of Business Administration, Faculty of Management Sciences, University of Benin, Nigeria

\section{Abstract}

Mentoring which is a process of tutoring a junior person in a workplace by a senior colleague is becoming more challenging especially in the university system. The objective of this study therefore is to provide empirical investigation in the Nigerian context on the challenges associated with mentoring for both the mentor and the protége in the university system. The study employed a survey research design. The population consists of all academic staff in three randomly selected universities in Edo state namely: University of Benin, Ambrose Ali University, and Igbinedion University. The research instrument used was a structured questionnaire administered to academics across different cadres. Data collected were analyzed using frequency, percentages, mean, standard deviation, exploratory factor analysis, $t$-test and analysis of variance (ANOVA). All statistical analyses were done using Statistical Package

\footnotetext{
* Correspondence should be addressed to Dr. Simon Ayo ADEKUNLE, Department of Business Administration, Faculty of Management Sciences, University of Benin, Nigeria
}

Email: adeksim@uniben.edu,adeksim@yahoo.com

https://orcid.org/0000-0002-4171-8903

(Received 23rd September 2020; Revised $4^{\text {th }}$ June 2021; Accepted 10 th June 2021 (C) OUSL)

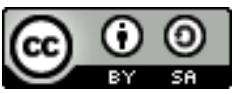

This article is published under the Creative Commons Attribution-Share Alike 4.0 International License (CC-BY-SA). This license permits use, distribution and reproduction in any medium; provided it is licensed under the same terms and the original work is properly cited. 
for the Social Sciences (SPSS 24). The study found that prominent mentoring challenges among Nigerian university academics include victimization, instant gratification, gender-based bias, work life imbalance and incivility. It was also found that mentoring challenges experienced by academics do not significantly differ based on demographic characteristics such as status, gender, age, qualification and work experience. The study recommends that universities and other tertiary institutions should promote an atmosphere of organizational harmony where faculty members will seek the growth of younger academic staff for the advancement of the educational system.

Keywords: Academics, challenges, mentor, mentoring, universities

\section{Introduction}

The act of mentoring is an age-long practice that dates back to ancient Greek mythology when Odysseus entrusted the care of his son Telemachus to the charge of an old man named Mentor who guided Telemachus to adulthood and saved his life several times (Cartwright, 2012). Inzer \& Crawford (2005) stated that mentoring is a one-to-one relationship that exists between the mentor and the protége with the aim of the expert (Mentor) voluntarily giving time to teach, support and encourage a younger, less experienced person (Protégé). Sawiuk, Taylor $\&$ Groom (2017) found that many organizations have come to recognize the importance of mentoring and coaching programs and have formalized systems of doing both. The world of work is rapidly changing in Nigeria with the influx of younger persons, women and other minorities into the workforce and the exit of older workers either voluntarily or involuntarily (Agbonifoh \& Idubor, 2016). It is therefore expedient that the experience and knowledge of the older workforce be passed on seamlessly to the younger generation through the act of mentoring and knowledge management (Maxwell, 1998).

Continuous reform and renewal of the educational system are germane (Walters, Robinson $\&$ Walters, 2020). This underscores the importance of mentoring in the educational system to build the requisite capacity to engage in result-oriented reforms. The importance of mentoring and its benefits to the organization, the 
mentor and protégé, have been demonstrated especially in the Western countries (Kram, 1985; Noe, 1988; Zachary, 2000; Leidenfrost et al., 2014). The situation may be slightly different in the Nigerian organizations as noted by Okurame (2008) because of the negative connotation of mentors as godfathers. The notion of godfatherism is best described as the idea that an employee is under the protection and influence of a more powerful person with the aim of the junior employees getting benefits, they may not ordinarily be entitled to them, and avoid punishment for infractions. As observed by Akanni (2011), mentoring should focus on helping protégé acquiring the requisite knowledge, experience and guidance to enable him or her to perform exceptionally on the job and in life generally. It is about getting the protégés to learn from the mentors what they may not ordinarily learn or for them to learn it faster and in greater depth.

Agbonifoh \& Idubor (2016) allude to the attitude of many young people in the workplace who regard the older generation as "old school" and the reciprocal perception by the older generation that the young ones have nothing to offer. These attitudes may make mentoring quite difficult because mentoring requires involvement and sacrifice on the part of the mentor and protégé.

Several studies have been done on the concept of mentoring in organizations in many parts of the world and there is a consensus on the need for, and the benefits of mentoring (Kram, 1985; Rothwell, 2005; Olowookere, 2012; Ekechukwu \& Horsfall, 2015; Tanoli, 2016). An informal mentoring system is in place within many organizations and formal mentoring is also greatly advocated (Inzer \& Crawford, 2005; Kolade, 2015; Sola, 2018).

Several studies have also been done in Nigeria concerning mentoring. The general approach of Nigerian studies has been to stress the importance and benefits of mentoring in organizations as a tool for accelerating employee performance, career growth, competencies and even for succession planning and staff retention (Elegbuanya, 2012; Ekechukwu \& Horsfall, 2015; Omale et al., 2017). Based on the review of extant literature, there is a paucity of empirical investigation in the Nigerian context on the challenges associated with mentoring for both the mentor and the protégé. 


\section{Research Objectives}

i. To identify mentoring challenges confronting academics in universities in Nigeria;

ii. To determine whether a significant difference exists in the forms of mentoring challenges confronting academics in Nigerian universities; and

iii. To examine the influence of demographic characteristics on academics' perception of different forms of mentoring challenges in Nigerian universities.

\section{Literature Review}

\section{Mentoring and its benefits}

The concept of mentoring is by no means a new one. The term was first used in 1616 and it implies a teacher (Cartwright, 2012). However, judging from the current definitions of the word mentor as a trusted counselor (Kram, 1985), guide (Moon, 2014), tutor (Azman, Muhammad \& Sebastian, 2009), coach (Collins, Brown \& Newman, 1987), it would seem that the mentoring function has been going on for as long as humans have existed. The Bible records the relationship between Moses and Joshua, Elijah and Elisha, and even Jesus Christ and his disciples; these were all forms of mentoring relationships. Invariably, the result of mentoring is for the mentor to at least reproduce himself in the protégé or to produce a protége that can surpass him in his field of expertise and to be able to say, as Jesus Christ said to his disciples 'he that believeth on me (follows my footsteps), the works that I do shall he do also; and greater works than these shall he do...' (John 14: 12. The Holy Bible KJV).

Rao (2010) defines mentoring as a relationship in which a senior manager in an organization assumes the responsibility for grooming a junior person. The relationship involves technical, interpersonal and political skills that are taught by the more experienced person to the less experienced person. Popoola, Adesopo \& Ajayi (2013) opine that it is the process whereby an experienced and highly empathic person called the mentor, assists and guides another individual called the protégé (whether male or female) in the development of their skills, knowledge and attitudes and their competence in the workplace. 
In the academic setting which is the focus of this study, Olasupo (2011) states that an academic mentor is usually a senior faculty member who guides a junior faculty member by way of advice, guidance, support and other relevant means in matters connected to the attainment of academic success; the protege, on the other hand, is the junior faculty member who is the beneficiary of the mentorship. Generally, it has been agreed that mentoring is one of the easiest and most effective methods of assisting individuals to develop the required skill sets in different organizations (Olasupo, 2011; Olowookere, 2012; Okurame, 2008; Ojokuku \& Sajuyuigbe, 2015; Sola, 2018).

The benefits of mentoring are not limited to the protége alone, the mentor and the organization also gain from the process. The importance of mentoring based on the benefits to these three categories - protégé, mentor, and organizations are discussed further: Benefits of mentoring for Protégés: Nnaji, Uko \& Nwafor (2015) aver that new and younger academic staff are often confronted by a new culture and tradition which is different from what they may have been used to in their previous places of work or institutions of learning. Nnaji et al. (2015) agree by stating that the range of duties that faces a new academic staff in the university can be quite daunting and if appropriate support is not given, it can lead to a host of problems for the staff. Some may be entering the world of work for the first time and hence would need guidance to navigate the new territory successfully.

Mentoring is also a way of enhancing the skill sets of junior academics. Ballet \& Kelchetermans (2009) opine that in fluid societies, it is important to stress continuous professional development if teachers are to successfully adapt to changes and cope with the pressure of meeting organizational standards. In Nigeria, the declining standards in the education sector are being continually decried (Ndaguba et al., 2018), the general opinion is that academic excellence which the country enjoyed in time past is fast decaying and it is all blamed on the "younger generation". A potent way of stopping this seeming downward spiral is to get the older generation of the "good old days" of academics to transfer knowledge through mentoring to the younger generation to regain the lost academic glory. Mentoring is another way for new academics to gain a professional identity. 
When coming into the academic system, the new employee may know little or nothing about the profession or the values of the profession. Through mentoring, mentors pass on the values and tenets of the profession; regulate the behavior of new employees by ensuring that they understand the professional ethics and requirements of their job (Hobson et al., 2015).

Benefits of Mentoring for Mentors: Mentors also benefit a great deal from the mentoring process personally and for the general good of the organization. The self-actualization which Maslow talks about in the need's theory comes into play here (Maslow, 1954). Mentors are usually well-established, experienced and accomplished people in their fields and life generally. After attaining this height, that is, they have actualized themselves, what is left for them is building the next generation that may surpass them. This feeling of being a part of and contributing to something that will outlive their physical presence in the organization gives a sense of purpose and deep satisfaction to these mentors.

Secondly, mentoring offers the mentor an opportunity to see new perspectives on the culture of the university. With the rapid changes in the world of work, organizational culture is also changing, therefore by interacting with the younger and newer generation; the mentor can grasp the changing dynamics of culture thus enabling him or her to stay in touch with the environment. Thirdly, mentoring gives mentors countless opportunities to share their experience and expertise. Some senior academics have been prompted to write books documenting their experience and expertise by their protégés so that many others can benefit from that wealth of information. This also causes the mentor to reflect on current practices to see if they are an improvement or not on former practices, to refine them. Mentoring also enables the mentor to focus on their ideas, behaviour and choices because they realize that junior academic staff are looking up to them in terms of morals and workplace ethics. In this way, standards are maintained, and younger academics have befitting role models on which to model their behaviours, ideas and choices. Mentoring also offers the mentor opportunities to increase his/her circle of friends and be recognized for his / her skills and experience (Aston University, 2020). 
Finally mentoring allows the mentors to mold the next generation of leaders by helping them build the requisite leadership skills. When mentoring is properly done and the mentoring relationship is well cultivated, the mentor remains relevant for life even, because from time to time, the protégé, no matter his/her current status will revert to the mentor when faced with thorny issues (Tjan, 2017).

Benefits of Mentoring for the University: A proper and well-structured mentoring programme is also of great importance to the university, and not just to the mentor and protégé. Firstly, it will help in the identification and retention of excellent staff. The mentoring process thrusts the mentor and protégé close together under many situations in the workplace. The mentor can observe, test and gauge the capabilities of the protégés and therefore able to identify those who have the skill sets that are valued by the organization. Such people are then carefully groomed, provided with training and learning opportunities and steered into positions of increasing responsibilities. A staff that has been so treated is more likely to develop some degree of loyalty to the organization and therefore less likely to entertain turnover intentions. This also helps the organization to avoid the hassles and costs associated with acquiring and training new staff (University of the People, 2020).

Another benefit for the organization is that when excellent staff are identified and retained in the organization, this will eventually raise the standard of the organization and enable it to compete favorably with other similar organizations.

A good mentoring programme will also increase diversity within the organization. One major challenge with mentoring is that mentors and protégés alike enter mentoring relationships with people alike them. The effect of this is that those people in the minority (females, minority ethnic groups, minority religions, the physically challenged, those with different sexual orientations and so on) are usually left out of mentoring relationships or are not properly mentored. An effective mentoring programme, however, will ensure that these groups are included and therefore well mentored so that their insignificant contributions will be made available to the organization. Their inclusion will bring fresh ideas, new perspectives and deeper 
understanding that if properly harnessed may become a competitive advantage for the organization (Lambert, 2016).

Finally, mentoring is an effective means of transmitting corporate culture within the organization and for increasing communication in the organization. Through mentoring, management's views can be passed on to protégés in a non-threatening, non-combative atmosphere where they have the liberty to question what they do not understand or agree with and management through the mentors will take time to explain and educate the protégés on them. Likewise, information about issues affecting the protégés can also be passed on to management through the mentors. In this way, the mentors form and become a link bridging the gap between younger employees and management thereby improving organizational communication.

\section{Need for Mentoring amongst Nigerian Academics}

Many studies have been undertaken to establish the need for mentoring among academic staff in Nigerian universities (Sola, 2018; Omale et al., 2017; Undiyaundeye \& Basake, 2017; Kolade, 2015; Nnaji et al., 2015). The consensus based on the works of the abovementioned scholars is that young academic staff just entering the university system face many challenges and that if not properly guided they may be unable to successfully overcome them at the appropriate time. In a study by Hassan, Baharom \& Mutalib (2017) on female academic staff in Nigerian universities, it was observed that the academic environment is fraught with many pitfalls for the unwary new entrant and at the same time, it holds many opportunities for growth and advancement that new academic staff may not be knowledgeable enough to take advantage of quickly. The role of mentoring therefore is to help the protége avoid the dangers inherent in lecturing and harness the positive potentials to ensure a rewarding academic career (Ekechukwu \& Horsfall, 2015).

According to Undiyaundeye \& Basake (2017), the pursuit of development by young academic staff in Nigeria is not without challenges, fears and anxieties and therefore mentoring can be an effective way of mitigating the stress of new lecturers, help them resolve challenges and help them achieve their career goals more readily. Mentoring has also been advocated as a means of transferring 
the skills which protégés need and can apply in diverse professional circumstances, promote learning and productive use of knowledge, definition of goals and career paths and job satisfaction (Okurame \& Balogun, 2005). Ayodeji \& Adebayo (2015) also indicate that mentoring can ensure and maintain effective school administration in Nigeria, because teaching is a multifaceted and complex task that demands the guidance and experience of senior academic staff. Undiyaundeye \& Basake (2017) also state that mentoring is needed in academics because it increases job satisfaction, self-confidence, enhances staff retention rate, encourages professional growth, develops competence and encourages collaboration while reducing competition. This view is also corroborated by Nnaji et al. (2015) who state that professional competence of newly employed lecturers could be significantly enhanced through mentoring. Sola (2018) also concurs when he states that mentoring has a significant influence on the career development of academic staff. Kolade (2015) advocates mentoring as a means of building a new generation of academics and responsible leadership. Omale et al. (2017) aver that mentoring improves staff retention and knowledge transfer in Nigerian universities.

\section{Challenging Factor to Mentoring Relationship}

Victimization: This involves the action of selecting an individual or group of individuals for inhumane or unjust treatment. Victimization in the workplace can be committed by both supervisors and subordinates, mentor and mentee, and among co-workers. This may be in form of minor abuses, denial of promotion, demotion, bearing false witness or false accusation and so on. In the university setting, victimization may include alienation of some colleagues because of their allegiance to certain senior academics, high tendency of a protégé becoming a target by other senior colleagues who are opposed to the mentor, fear of sexual harassment, as well as fear of being branded as the "mentor's boy or girl" by peers and other faculty members.

Instant gratification: This is the desire to experience pleasure or fulfillment without delay or deferment. Instant gratification behaviors can be detrimental by reprogramming individual mindsets and cause distraction from more meaningful and rewarding pursuits. The culture of instant gratification can lead to destructive financial, social, 
and health outcomes. Some young academics especially in public universities in Nigeria lack interest in anything that will not immediately yield financial gains for them. As a result of this, Agbonifoh \& Idubor (2016) assert that some mentors or senior colleagues are unwilling to introduce protégés to lucrative aspects of the job such as consultancy, book writing, adjunct lecturing among others.

Gender-based bias: This is the predisposition to prefer one gender over another. According to Bailey (2019), "gender bias is a form of unconscious bias, or implicit bias, which occurs when one individual unconsciously attributes certain attitudes and stereotypes to another person or group of people". It entails discriminatory practices against individuals in the workplace because of gender differences. Gender bias is a serious challenge in a mentoring relationship as mentees may be afraid of being romantically linked to the mentor in a different gender mentoring relationship. It is also possible that preferred gender may be scarce for proteges to select from. There is also a high tendency for mentoring relationship to become too personal for either the mentor or the mentee.

Work-life Imbalance: Work-life balance entails fair allocation of time for both work and other aspects of life which include family and personal-related issues. Talukder, Vickers \& Khan (2018) identified the benefits of work-life balance to include an increase in efficiency and productivity; decline in staff absenteeism, illness and stress; motivated workforce and higher retention of workforce. Despite these benefits, work-life imbalance which is the inability to fairly allocate time for work and other activities serve as a challenge in a mentoring relationship as mentors may be too engaged thereby unable to pay adequate attention to the mentoring needs of proteges. Especially in the Nigerian setting, what other people may say about a perceived cordial relationship between mentor and protégé may prevent some mentors from spending quality time with their proteges.

Incivility: This can be described as bad behaviour characterized by rudeness, discourteous behaviours, as well as lack of regards or consideration toward others in the organization (Gabriel et al., 2018). Incivility in the workplace leads to low intensity deviant behaviour 
with ambiguous intent to harm the target, in violation of workplace norms for mutual respect (Anderson \& Pearson, 1999). Examples of incivility include making nasty and demeaning comments to/about someone, cutting people off while they are yet speaking, browbeating, undermining one's credibility in the presence of other people. In a mentoring relationship, incivility may include lack of freedom and opportunities for the protégé to freely speak about his ideas and feelings, a lack of reverence and respect by junior academics for the expertise and person of the mentor, rebuffing or disdaining the attempts of other individuals, and so on.

\section{Theoretical Framework}

This study is built on the apprenticeship model. Barab et al. (2001) define apprenticeship as a process where apprentices work side-byside with an expert to learn a specific task. Traditionally, apprenticeship was associated with the training of craftsmen and later in vocational training; however, in recent times, it has been extended to other types of training. Nielson \& Kvale (1997) indicate that the apprenticeship model has now been introduced outside of the traditional vocational education as a general pedagogical model. Apprenticeship as a term has gone beyond the description of the statutory institutional structures that dominate vocational training to becoming a general metaphor for a relationship where a novice (protégé) learns from an experienced person (mentor). Nielsen \& Kvale (1997) discuss four things that characterize the apprenticeship model: participation in a community of practice, professional identity, learning through imitations of the master and that the qualities of work are evaluated through practice.

Wegner - Trayner and Wegner - Trayner (2015) define communities of practice as groups of people who share a concern or a passion for something they do and learn how to do it better as they interact regularly. The communities of practice have three main characteristics that are very important or that must exist before a community can be called a community of practice and they are the domain, the community and the practice. According to Wenger Trayner \& Wenger - Trayner (2015), the domain refers to the commitment that members must have to the community and involves a shared competence that differentiates members from non-members. 
The members value their collective competence and learn from each other. The community means that members of the community of practice engage in joint accounts and discussions, assist one another and share information (Cheng, 2011). Relationships are built that allow them to learn from each other, there is active interaction which may not necessarily be daily. Lastly, the practice refers to members of the community of practice being practitioners, they share practice by developing a joint repertoire of resources - experiences, stories, tools, methods of handling recurring challenges. This happens over time and sustained interaction.

In a community of practice, there are several types of mentoring relationships going on. The traditional mentor - protégé, is available where protégés have access to several mentors to aid their development (Menges, 2016). Peer mentorship also goes on the communities of practice because people come together to share ideas and learn from each other (Holland, 2018). The internet has made it possible for the members of a community of practice to be in various locations and still be able to interact closely. The benefits for protégés in belonging to a community of practice are enormous. As observed by Agbonifoh \& Idubor (2016), the protégé learns by taking part in a group of competent practitioners of his profession, to becomes more and more competent until he becomes a very competent member of the professional community.

Professional identity as explained by Hirsch, Lloyd \& Kennedy (2019) is acquired by the protégé as he acquires and masters' new skills by learning and completing practical assignments that are increasingly become tougher. The protégé is engaged in a reflective conversation soon after the completion of the assignment to ensure that he understands the processes and that his success was not just a fluke. In learning through imitation of the master (mentor), the protégé not only observes the work of the mentor or other skilled professionals in the community, but he must also imitate it (Cheng, 2012). The mentoring process here is quite clear, the mentor demonstrates how a task should be properly executed, then the protége begins to practice how to execute the same task, he is corrected and guided by the master until he becomes proficient at the task or acquires the skill. 
Finally, the work of the protégé will be evaluated through practice. The mentor has accumulated knowledge about the required skills necessary to execute a task therefore he will judge the quality of the protégé's work based on his knowledge, functionality and feedback from others. Therefore, this model could be instrumental in dealing with mentoring challenges of victimization, instant gratification, gender-based bias, work-life imbalance and incivility by evaluating mentee's background in terms of knowledge and skill, scrutinize mentee's motives and drives for engaging in a mentoring relationship, deal with the inexperience of mentee, address possible misconceptions that mentee may have about mentoring and set challenging but achievable goals for the relationship.

\section{Methodology}

\section{Research design}

This study employed a survey research design. The design was adopted because of its high flexibility of data collection, potential to build a rapport and a high degree of diversity of questions to capture various perceptions of respondents (Malhotra, Birks \& Wills, 2013).

\section{Population, sample size and sampling technique}

The population consists of all academic staff in three randomly selected universities in Edo State namely: University of Benin (Federal University); Ambrose Ali University, Ekpoma (State University); and Igbinedion University Okada (Private University). These universities were chosen because they are the oldest universities in the State. Only those academic staff who have spent at least twelve months (12) in the university were included in the study. This is because new entrants in the university might not be aware of some of the issues the study seeks to investigate. Based on information from the registries of the various universities, the total academic staff strength of these universities is 3,054 as of July 2018. The breakdown is as follows: University of Benin $(1,824)$, Ambrose Alli University (680) and Igbinedion University (550).

The sample size for this study was 459; however, only 230 questionnaires could be retrieved, of which only 177 copies of the questionnaire were found usable due to non-response or partial 
completion of the remaining 53 copies. The details are presented in Table 1

Table 1: Questionnaire distribution to sampled universities

\begin{tabular}{|c|l|c|c|c|c|c|}
\hline \multirow{2}{*}{$\mathrm{S} / \mathrm{N}$} & \multirow{2}{*}{ Institution } & \multirow{2}{*}{ Population } & \multicolumn{3}{|c|}{ Questionnaire } & \multirow{2}{*}{$\%$} \\
\cline { 4 - 6 } 1 & $\begin{array}{l}\text { University of } \\
\text { Benin }\end{array}$ & 1824 & 274 & 150 & 134 & 75.7 \\
\hline 2 & $\begin{array}{l}\text { Ambrose Alli } \\
\text { University }\end{array}$ & 680 & 102 & 50 & 31 & 17.5 \\
\hline 3 & $\begin{array}{l}\text { Igbinedion } \\
\text { University }\end{array}$ & 550 & 83 & 30 & 12 & 6.8 \\
\hline \multicolumn{2}{l|l}{ Total } & 3054 & 459 & 230 & 177 & 100 \\
\hline
\end{tabular}

Table 1 shows that 459 copies of questionnaire were administered while 230 were retrieved. 177 copies of the questionnaire were found to be valid and useable. The distribution of the valid responses for the universities is: University of Benin (75.7\%); Ambrose Alli University (17.5\%); and Igbinedion University (6.8\%).

Copies of the questionnaire were administered using convenience sampling to the academic staff in the three universities. Though convenience sampling was used, the sample size requirement could not be met. However, the researchers ensured that copies of the questionnaire were administered to the different categories of academic staff in the selected universities to provide a comprehensive assessment of the subject matter.

\section{Instrumentation}

The research instrument for this study is a structured questionnaire. The questionnaire is designed in sections (A and B). Section A consists of personal information about the respondents. Section B consists of questions on the challenges of mentoring. The questions in Section B are designed on a 5-point Likert scale of 5, 4, 3, 2, and 1 for Strongly Agree, Agree, Neutral, Disagree and Strongly Disagree respectively. 


\section{Validity and reliability}

The face and content validity of the research instrument were based on the meticulous scrutiny and evaluation of senior faculty members who are experts in Human Resource Management and Sociology. With respect to the reliability of the instrument, a pilot test was conducted to aid in testing the reliability of the research instrument. Fifty (50) copies of the questionnaire were administered to both senior and junior academic staff. The Statistical Package for the Social Sciences (SPSS 24.0) software was used to ascertain the internal consistency as demonstrated by the Cronbach alpha value of 0.888 .

\section{Method of data analysis}

Data generated from the use of structured questionnaire were analyzed using descriptive statistics such as frequency distribution, percentages, mean and standard deviation. Factor analysis was used to identify the mentoring challenges confronting academics in Nigerian universities. T-Test was conducted to find out whether significant differences exist between two demographic variables (status and gender) and the different forms of mentoring challenges. Analysis of variance (ANOVA) was used to test whether significant differences exist between the remaining respondents' demographics (age, qualification and work experience) and the different forms of mentoring challenges. All analyses were conducted using Statistical Package for Social Sciences (SPSS 24) at 5\% level of significance.

\section{Results and Discussions}

This section presents the analysis of the data collected with the questionnaire administered to academics in three selected universities in the Edo state. The results are presented in line with the research objectives.

\section{Respondents' demographics information}

The demographic profile of respondents such as status, gender, age, highest educational qualification, and work experience are presented in Tables 2 below: 
Table 2: Respondents' demographics

\begin{tabular}{|c|c|c|}
\hline Variable & Category & $\begin{array}{c}\text { Frequency and } \\
\text { Percent }\end{array}$ \\
\hline \multirow{3}{*}{ Status } & Senior Academic Staff & 69 (38.9\%) \\
\hline & Junior Academic Staff & $108(61.1 \%)$ \\
\hline & Total & $177(100 \%)$ \\
\hline \multirow{3}{*}{ Gender } & Male & $114(67.5 \%)$ \\
\hline & Female & $55(32.5 \%)$ \\
\hline & Total & $169(100 \%)$ \\
\hline \multirow{6}{*}{ Age } & 18-24years & $22(12.5 \%)$ \\
\hline & 25-35years & $47(26.7 \%)$ \\
\hline & 36-45years & $71(40.3 \%)$ \\
\hline & 46-55years & $25(14.2 \%)$ \\
\hline & 56years and above & $11(6.3 \%)$ \\
\hline & Total & $176(100 \%)$ \\
\hline \multirow{4}{*}{ Qualification } & $\mathrm{PhD}$ & $74(42.5 \%)$ \\
\hline & Masters & $68(39.1 \%)$ \\
\hline & First Degree & $32(18.4 \%)$ \\
\hline & Total & $174(100 \%)$ \\
\hline \multirow{5}{*}{ Work Experience } & Less than 3years & $55(32.4 \%)$ \\
\hline & 3-6years & $47(27.6 \%)$ \\
\hline & 7-12years & $41(24.1 \%)$ \\
\hline & Above 12years & 27 (15.9\%) \\
\hline & Total & $170(100 \%)$ \\
\hline
\end{tabular}

Note: Senior academic staff include Professors; Associate Professor; and Senior Lecturers while junior academic staff include Lecturer I; Lecturer II; Assistant Lecturers and Graduate Assistants.

Table 1 shows that majority of the respondents are in junior category, which are 108 accounting for $61.1 \%$ of the total respondents. The senior academic staff were 69 . This represents $38.9 \%$ of the total respondents. Table 1 also shows that majority of the respondents are male, who are 114 accounting for $67.5 \%$ of the total respondents. The female respondents were 55 . This represents $32.5 \%$ while 8 respondents did not indicate their gender. The age distribution shows that majority of the respondents (71) are between 36 and 45years old. This category accounts for $40.3 \%$ of the total respondents. This is followed by $25-35$ years old $(47,26.6 \%)$ and $46-55$ years $(25,14.2 \%)$. 
Respondents within the age category of 18-24years account for $12.5 \%$. Finally, respondents that are 56years old and above account for 6.3\%. Only 1 respondent did not indicate his/her age category. Majority of the respondents (74) had Ph.Ds. This category accounts for $42.5 \% .68$ (39.1\%) of the respondents have Master's Degrees while $32(18.4 \%)$ of the respondents have first degrees. Three (3) of the total respondents did not indicate their highest educational qualification. The results further show that majority of the respondents (55) have less than 3years' working experience as lecturers which accounts for $32.4 \%$ of the total respondents. $27.6 \%$ of them have worked for three to six years while $24.1 \%$ have worked for 7 to 12 years. Respondents who have worked for more than 12years accounted for $15.9 \%$ of the total respondents. $7(3.9 \%)$ of the total respondents do not indicate their years of experience.

\section{Identification of mentoring challenges among academics in Nigerian universities}

To identify the mentoring challenges confronting academics is Nigeria universities the 18-item instrument was subjected to exploratory factor analyses to identify the factors. The results are shown in Table 3:

Table 3: Exploratory factor analyses of research items

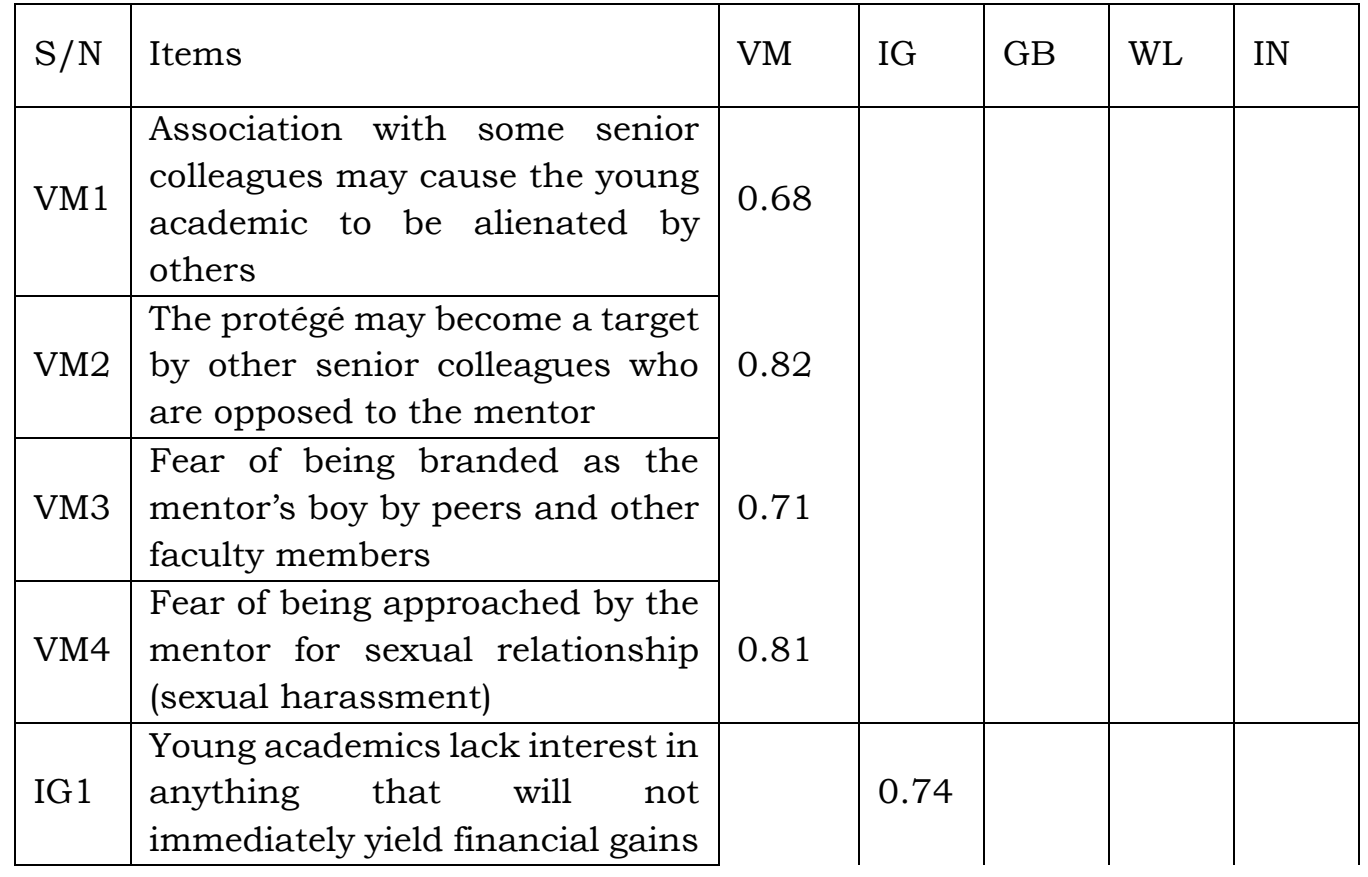




\begin{tabular}{|c|c|c|c|c|c|c|}
\hline IG2 & $\begin{array}{l}\text { Mentors' unwillingness to } \\
\text { introduce protégés to lucrative } \\
\text { aspects of the job e.g. } \\
\text { consultancy, book writing, } \\
\text { adjunct lecturing }\end{array}$ & & 0.69 & & & \\
\hline GB1 & $\begin{array}{l}\text { Fear of being romantically linked } \\
\text { to the mentor in a different } \\
\text { gender mentoring relationship }\end{array}$ & & & & & \\
\hline GB2 & $\begin{array}{l}\text { Mentors of the preferred gender } \\
\text { are lacking }\end{array}$ & & & 0.70 & & \\
\hline GB3 & $\begin{array}{l}\text { Inadequate number of female } \\
\text { mentors }\end{array}$ & & & 0.76 & & \\
\hline GB4 & $\begin{array}{l}\text { I would prefer to mentor a } \\
\text { protégé of the same gender as } \\
\text { me }\end{array}$ & & & 0.61 & & \\
\hline GB5 & $\begin{array}{l}\text { The mentoring relationship } \\
\text { might become too personal for } \\
\text { my liking }\end{array}$ & & & 0.66 & & \\
\hline WL1 & $\begin{array}{l}\text { Mentors are usually quite busy } \\
\text { and are hence unable to pay } \\
\text { adequate attention to the } \\
\text { mentoring needs of the protégé }\end{array}$ & & & & 0.65 & \\
\hline WL2 & $\begin{array}{l}\text { Inability to spend quality time } \\
\text { with the mentor because of what } \\
\text { people will say }\end{array}$ & & & & 0.78 & \\
\hline WL3 & $\begin{array}{l}\text { Lack of work - life balance } \\
\text { makes mentoring difficult }\end{array}$ & & & & 0.55 & \\
\hline IN 1 & $\begin{array}{l}\text { Protégés are usually unable to } \\
\text { measure up to the standards of } \\
\text { the mentor }\end{array}$ & & & & & 0.62 \\
\hline IN2 & $\begin{array}{l}\text { Lack of freedom and } \\
\text { opportunities for the protégé to } \\
\text { freely speak about his ideas and } \\
\text { feelings }\end{array}$ & & & & & 0.78 \\
\hline IN3 & $\begin{array}{l}\text { Lack of reverence and respect by } \\
\text { junior academic for the expertise } \\
\text { and person of the mentor }\end{array}$ & & & & & 0.81 \\
\hline IN4 & $\begin{array}{l}\text { There is someone I would have } \\
\text { loved to mentor but he rebuffed } \\
\text { my attempts at mentoring }\end{array}$ & & & & & 0.72 \\
\hline \multicolumn{2}{|c|}{ Eigenvalues } & 6.57 & 2.56 & 1.53 & 1.23 & 1.04 \\
\hline
\end{tabular}




\begin{tabular}{|l|l|l|l|l|l|}
\hline Percentage of variation & 36.5 & 14.2 & 8.5 & 6.9 & 5.8 \\
\hline Kaiser-Meyer-Olkin (KMO) & 0.731 & \\
\hline Bartllet's test of sphericity & 1827.345 \\
\hline Sig. & 0.000 \\
\hline Total variation & $71.9 \%$ \\
\hline
\end{tabular}

Note: $\mathrm{VM}=$ Victimization, $\mathrm{IG}=$ Instant Gratification, $\mathrm{GB}=$ Genderbased bias, $\mathrm{WL}=$ Work life imbalance and $\mathrm{IN}=$ Incivility.

Based on the results of the factor analysis in Table 3, $71.9 \%$ of the total variance was explained with an eigenvalue greater than 1.0 by generating five (5) factors or challenges labeled as Victimization (36.5\%), Instant Gratification (14.2\%), Gender-Based Bias (8.5\%), Work Life Imbalance (6.9\%) and Incivility (5.8\%). The Kaiser-MeyerOlkin (KMO) value was 0.731 while the Bartlett's test of sphericity of 1827.345 was significant at the 0.000 level. The KMO value of 0.731 is adequate since the value is greater than 0.5 .

\section{Determination of statistical differences in the forms of mentoring challenges}

To determine whether significant difference exists in the forms of mentoring challenges among academics in Nigerian universities, analysis of variance (ANOVA) was used. The result is shown in Table 4:

Table 4: ANOVA Result of different forms of mentoring challenges

\begin{tabular}{|c|c|c|c|c|c|}
\hline Source of Variation & $\begin{array}{l}\text { Sum of } \\
\text { Squares }\end{array}$ & $\mathrm{df}$ & $\begin{array}{l}\text { Mean } \\
\text { Square }\end{array}$ & $\mathrm{F}$ & Sig. \\
\hline Between Groups & 15.9390 & 4 & 3.9847 & \multirow{3}{*}{4.6468} & \multirow{3}{*}{0.001} \\
\hline Within Groups & 754.6151 & 880 & \multirow[t]{2}{*}{0.8575} & & \\
\hline Total & 770.5541 & 884 & & & \\
\hline \multicolumn{6}{|c|}{ Post-Hoc-Test using Student-Newman-Keuls } \\
\hline \multicolumn{2}{|c|}{ Forms of mentoring challenges } & $\mathrm{N}$ & \multicolumn{3}{|c|}{ Subset for alpha $=0.05$} \\
\hline
\end{tabular}




\begin{tabular}{llll}
\hline Incivility & 177 & 2.737 & \\
Work Life Imbalance & 177 & 2.918 & \\
Gender Based Bias & 177 & & 2.982 \\
Instant Gratification & 177 & & 3.062 \\
Victimization & 177 & & 3.127 \\
Sig. & & 0.067 & 0.146 \\
\hline
\end{tabular}

The result in Table $4(F=4.6468 ; \rho=0.001)$ shows that there is a statistically significant difference in the evaluation of the various forms of mentoring challenges (victimization, instant gratification, gender-based bias, work life imbalance and incivility) by respondents (academics) in the Nigerian universities. Due to the significant result of the ANOVA output, post-hoc-test using Student-Newman-Keuls (S$\mathrm{N}-\mathrm{K})$ was conducted to further categorize the forms of mentoring challenges confronting academics. The result shows that items in Category II (Gender Based Bias [2.982], Instant Gratification [3.062] and Victimization [3.127]) were significantly rated higher than items in Category I (Incivility [2.737] and Work Life Imbalance [2.918]).

\section{Demographic characteristics and mentoring challenges among academics}

The influence of demographic characteristics such as status, gender, age, qualification and work experience on the different forms of mentoring challenges namely victimization, instant gratification, gender-based bias, work life imbalance and Incivility are presented in Table 5: 
Table 5: Demographic characteristics and mentoring challenges among academics

\begin{tabular}{|c|c|c|c|c|c|c|c|}
\hline \multirow[b]{2}{*}{$\begin{array}{l}\text { Variabl } \\
\text { e }\end{array}$} & \multirow[b]{2}{*}{$\begin{array}{l}\text { Catego } \\
\text { ry }\end{array}$} & \multirow[b]{2}{*}{$\begin{array}{l}\text { test } \\
\text { statist } \\
\text { ic }\end{array}$} & \multicolumn{5}{|c|}{ Forms of Mentoring Challenges } \\
\hline & & & $\begin{array}{l}\text { Victimi } \\
\text { zation }\end{array}$ & $\begin{array}{l}\text { Instant } \\
\text { Gratifi } \\
\text { cation }\end{array}$ & $\begin{array}{l}\text { Gender } \\
\text { based } \\
\text { bias }\end{array}$ & $\begin{array}{l}\text { Work } \\
\text { Life } \\
\text { Imbala } \\
\text { nce }\end{array}$ & $\begin{array}{l}\text { Incivili } \\
\text { ty }\end{array}$ \\
\hline \multirow{2}{*}{ Status } & $\begin{array}{l}\text { Junior } \\
\text { Acade } \\
\text { mics }\end{array}$ & \multirow{2}{*}{ t-test } & \multirow{2}{*}{$\begin{array}{c}0.390 \\
(0.697)\end{array}$} & \multirow{2}{*}{$\begin{array}{l}-0.561 \\
(0.559)\end{array}$} & \multirow{2}{*}{$\begin{array}{l}0.034 \\
(0.973)\end{array}$} & \multirow{2}{*}{$\begin{array}{l}0.195 \\
(0.846)\end{array}$} & \multirow{2}{*}{$\begin{array}{l}- \\
0.325 \\
(0.746)\end{array}$} \\
\hline & $\begin{array}{l}\text { Senior } \\
\text { Acade } \\
\text { mics }\end{array}$ & & & & & & \\
\hline \multirow{2}{*}{$\begin{array}{l}\text { Gende } \\
\mathrm{r}\end{array}$} & Male & \multirow{2}{*}{ t-test } & \multirow{2}{*}{$\begin{array}{l}1.581 \\
(0.116)\end{array}$} & \multirow{2}{*}{$\begin{array}{c}0.018 \\
(0.922)\end{array}$} & \multirow{2}{*}{$\begin{array}{l}0.928 \\
(0.355)\end{array}$} & \multirow{2}{*}{$\begin{array}{c}1.637 \\
(0.104)\end{array}$} & \multirow{2}{*}{$\begin{array}{l}0.001 \\
(0.999)\end{array}$} \\
\hline & Female & & & & & & \\
\hline \multirow{4}{*}{ Age } & 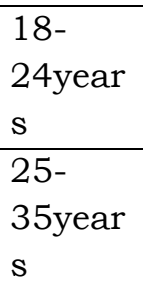 & \multirow{4}{*}{$\begin{array}{l}\text { ANOV } \\
\text { A }\end{array}$} & \multirow{4}{*}{$\begin{array}{c}0.239 \\
(0.916)\end{array}$} & \multirow{4}{*}{$\begin{array}{l}0.873 \\
(0.481)\end{array}$} & \multirow{4}{*}{$\begin{array}{c}0.937 \\
(0.444)\end{array}$} & \multirow{4}{*}{$\begin{array}{c}0.799 \\
(0.527)\end{array}$} & \multirow{4}{*}{$\begin{array}{l}1.208 \\
(0.070\end{array}$} \\
\hline & $\begin{array}{l}36- \\
45 y e a r \\
s\end{array}$ & & & & & & \\
\hline & $\begin{array}{l}\text { 46- } \\
55 \text { year } \\
\mathrm{s}\end{array}$ & & & & & & \\
\hline & $\begin{array}{l}56 y e a r \\
\mathrm{~s} \text { and } \\
\text { above }\end{array}$ & & & & & & \\
\hline \multirow{3}{*}{$\begin{array}{l}\text { Qualifi } \\
\text { cation }\end{array}$} & Ph.D & \multirow{3}{*}{$\begin{array}{l}\text { ANOV } \\
\text { A }\end{array}$} & \multirow{3}{*}{$\begin{array}{l}1.514 \\
(0.223)\end{array}$} & \multirow{3}{*}{$\begin{array}{c}0.864 \\
(0.423)\end{array}$} & \multirow{3}{*}{$\begin{array}{l}0.737 \\
(0.480)\end{array}$} & \multirow{3}{*}{$\begin{array}{l}1.188 \\
(0.307)\end{array}$} & \multirow{3}{*}{$\begin{array}{r}0.327 \\
(0.722)\end{array}$} \\
\hline & $\begin{array}{l}\text { Master } \\
\mathrm{s}\end{array}$ & & & & & & \\
\hline & $\begin{array}{l}\text { First } \\
\text { Degree }\end{array}$ & & & & & & \\
\hline \multirow{2}{*}{$\begin{array}{l}\text { Work } \\
\text { Experi } \\
\text { ence }\end{array}$} & $\begin{array}{l}\text { Less } \\
\text { than } \\
\text { 3years }\end{array}$ & \multirow{2}{*}{$\begin{array}{l}\text { ANOV } \\
\text { A }\end{array}$} & \multirow{2}{*}{$\begin{array}{l}3.307 \\
(0.022)\end{array}$} & \multirow[t]{2}{*}{$\begin{array}{l}1.081 \\
(0.359)\end{array}$} & \multirow{2}{*}{$\begin{array}{c}1.041 \\
(0.376)\end{array}$} & \multirow[t]{2}{*}{$\begin{array}{l}0.267 \\
(0.849)\end{array}$} & $\begin{array}{l}0.590 \\
(0.623)\end{array}$ \\
\hline & $\begin{array}{l}3- \\
\text { 6years }\end{array}$ & & & & & & \\
\hline
\end{tabular}




\begin{tabular}{|c|c|c|c|c|c|c|c|}
\hline \multirow{4}{*}{$\begin{array}{l}\text { Variabl } \\
\text { e }\end{array}$} & \multirow[b]{2}{*}{$\begin{array}{l}\text { Catego } \\
\text { ry }\end{array}$} & \multirow{4}{*}{$\begin{array}{l}\text { test } \\
\text { statist } \\
\text { ic }\end{array}$} & \multicolumn{5}{|c|}{ Forms of Mentoring Challenges } \\
\hline & & & $\begin{array}{l}\text { Victimi } \\
\text { zation }\end{array}$ & $\begin{array}{l}\text { Instant } \\
\text { Gratifi } \\
\text { cation }\end{array}$ & $\begin{array}{l}\text { Gender } \\
\text { based } \\
\text { bias }\end{array}$ & $\begin{array}{l}\text { Work } \\
\text { Life } \\
\text { Imbala } \\
\text { nce }\end{array}$ & $\begin{array}{l}\text { Incivili } \\
\text { ty }\end{array}$ \\
\hline & $\begin{array}{l}7- \\
12 y e a r \\
\text { s }\end{array}$ & & & & & & \\
\hline & $\begin{array}{l}\text { Above } \\
12 \text { year } \\
\mathrm{s}\end{array}$ & & & & & & \\
\hline
\end{tabular}

T-Test was conducted to find out whether significant differences exist between two demographic variables (status and gender) and the different forms of mentoring challenges. The use of t-test was because the variables (status and gender) involve only two categories each. The results in Table 5 showed that victimization $\{t=0.390 ; p=0.697\}$, instant gratification $\{\mathrm{t}=-0.561 ; \mathrm{p}=0.559\}$, gender-based bias $\{\mathrm{t}=0.034$; $\mathrm{p}=0.973\}$, work life imbalance $\{\mathrm{t}=0.195 ; \mathrm{p}=0.846\}$ and Incivility $\{\mathrm{t}=-$ $0.325 ; \mathrm{p}=0.746$, do not significantly differ by academics' status. Similarly, the results showed that victimization $\{\mathrm{t}=1.581 ; \mathrm{p}=0.116\}$, instant gratification $\{t=0.018 ; \mathrm{p}=0.922\}$, gender-based bias $\{t=0.928$; $\mathrm{p}=0.355\}$, work life imbalance $\{\mathrm{t}=1.637 ; \mathrm{p}=0.104\}$ and Incivility $\{t=0.001 ; p=0.999\}$ do not significantly differ by academics' gender.

Analysis of variance (ANOVA) was used to test whether significant differences exist between the remaining respondents' demographics (age, qualification and work experience) and the different forms of mentoring challenges. The result in Table 5 shows that the forms of mentoring challenges (victimization, instant gratification, genderbased bias, work life imbalance and Incivility) do not significantly differ based on respondents' demographics such as age, qualification and work experience except for victimization and work experience $\{\mathbf{t = 3 . 3 0 7 ;} \mathbf{p = 0 . 0 2 2}\}$ that is significant at $5 \%$ level of significance.

\section{Discussion}

This study identified victimization, instant gratification, gender-based bias, work-life imbalance and incivility as some of the mentoring challenges confronting university academics in Nigeria. Victimization 
in a mentoring relationship in the university system may include alienation of some colleagues because of their allegiance to certain senior academics, high tendency of a protégé becoming a target by other senior colleagues who are opposed to the mentor, fear of sexual harassment, as well as fear of being branded as the mentor's 'boy or girl' by peers and other faculty members. According to Rodriguez \& Sjostrom (2000), the mentors see themselves as older, wiser, having reached the pinnacle of their careers and holding all the power in the mentoring relationship. Some mentors may overawe the new academic, treat him as a mere 'errand boy/girl' and fail to impart any knowledge to him/her. This act of superiority may make the protégé feel resentful and begin to avoid the mentor since he/she cannot perceive any benefit from the relationship. A mentoring style that is purely hierarchical and does not include a collaborative or communal style is bound to breed these types of problems. Inappropriate choice of mentor/protégé, unrealistic expectations from the relationship by the parties, feelings of superiority/inferiority can create serious problems with the mentoring relationship. According to Dabiri \& Olorunleke (2006), the mentoring programme is built on trust and respect, where this is lacking, the relationship is doomed to fail.

Instant gratification impedes effective mentoring as discussed in this study. This is further reiterated by Undiyaundeye \& Basake's (2017) finding that the challenges to effective mentoring in the academia include the inability and unwillingness of young academics to follow instructions from mentors, due to the "get rich quick" mentality, the inability of the institution to manage personnel and ensure good community partnerships, inability and unwillingness of the mentors to support subordinate professional growth and finally, the inability of the school management to sanction untoward behaviour by young academics due to godfatherism. To deal with the challenges confronting the mentoring programme, participants in the mentoring exercise should be committed to their roles and responsibilities (Al Makhamreh \& Stockley, 2020).

Incivility is another challenge in mentoring relationship as preferred mentors sometimes decline protégés' requests for mentorships. Some senior academics who ought to act as mentors to new and younger lecturers are hardly available and accessible. Many professors are 
either on sabbatical in other universities, leave of absence, or are busy as adjunct lecturers, external examiners and consultants elsewhere. This creates a situation where the younger lecturers are left without mentors to who they can relate with. The senior academics hurriedly attend to proteges when they are available; they are saddled with other responsibilities such as Deanships, Headships and other positions within the university that make it difficult for them to have a meaningful mentoring relationship with their protégés if they have any. According to Hoy \& Spero (2005), the most frequently anticipated characteristic of effective mentors is the willingness and ability to nurture another person. Nnaji et al. (2015) add that the mentor should be people-oriented, open-minded, flexible, empathetic, collaborative, willing to make time and space for productive discussions, establish an equitable relationship and so on. These are obvious activities that require time and commitment. In a similar vein, gender bias is identified as a serious challenge in mentoring relationship as mentees may be afraid of being romantically linked to the mentor. It is also possible that preferred gender may be scarce for proteges to select from. Work-life imbalance serves as a challenge in a mentoring relationship as mentors may be too engaged thereby unable to pay adequate attention to the mentoring needs of proteges. For instance, what other people may say about a perceived cordial relationship between mentor and protégé in Nigerian universities may prevent some mentors from spending quality time with their proteges.

It was also found that mentoring challenges such as victimization, instant gratification, gender-based bias, work-life imbalance and Incivility do not significantly differ based on demographic characteristics such as status, gender, age, qualification and work experience. This implies that respondents' evaluation of mentoring challenges does not substantially differ based on their status which was broadly categorized into senior academic staff (Professors; Associate Professor; and Senior Lecturers) and junior academic staff (Lecturer I; Lecturer II; Assistant Lecturers and Graduate Assistants), gender, age, qualification and work experience. 


\section{Conclusion and Research Implications}

Considering the importance that many organizations attach to mentoring programs and the benefits that have been demonstrated to accrue from it, the concept must also be studied in relation to academics in Nigerian Universities. This study provides information on the challenges associated with the mentoring relationship among academics. The information generated by this study will help Universities to embark on or improve their mentoring programs as a way of improving service delivery. Moreover, it will be useful for educational policymakers to enable them to make policies that will harness the vast potentials that mentoring offers. The study found that the major challenges encountered by academics in mentoring relationships include victimization, instant gratification, genderbased bias, work-life imbalance and incivility.

Firstly, universities and other tertiary institutions should promote an atmosphere of organizational harmony where faculty members will seek the growth of younger academic staff for the advancement of the educational system.

Secondly, the compensation packages of lecturers should be appreciably enhanced to curb the worrisome culture of instant gratification that promotes corruption and other questionable acts among lecturers. Also, a reorientation of the values that are important to the university system should be taught and enforced across the university system.

Finally, more females should be encouraged to not only seek higherlevel academic positions within the university, they should also be urged to take up mentoring of younger faculty members by making themselves more available to address the problem of gender-based bias in mentorship.

\section{Limitations and Suggestions for Further Studies}

One of the limitations of this study is the sample size used. The sample size was originally determined to be 459 . Due to non-response or partial completion of some of the questionnaires, only 177 copies 
were used for data analyses out of the 230 copies retrieved. Secondly, the use of factor analysis requires at least ten participants per item for accurate loading and analysis. This could not be achieved in this study as only 177 responses were obtained instead of 180 responses required. However, the difference of 3 responses may not pose any significant alteration to the research outcomes. Finally, the instrument used for this study was the self-report questionnaire; future studies should include interviews and focus studies to get more accurate information and explore other areas that may not be adequately captured with the use of a questionnaire.

\section{References}

Agbonifoh, B. A. \& Idubor, E. E. (2016). Workforce diversity and classism in a public university setting. Nigerian Academy of Management Journal, $10(1$ and 2), $74-85$.

Akanni, A. A. (2011). Mentoring relationship: A protégé experience in A. A. Olowu (Ed.). Mentoring: A key issue in human resource management (pp 114 - 121). Ile-Ife. The Ife center for psychological studies.

Al Makhamreh, M. \& Stockley, D. (2020). Mentoring as meaningful professional development: The influence of mentoring on inservice teachers' identity and practice. International Journal of Mentoring and Coaching in Education, 9(1), 1-20.

Andersson, L. M. \& Pearson, C. M. (1999). Tit for tat? The spiraling effect of incivility in the workplace. Academy of Management Review, 24, 452-471.

Aston University (2020). Benefits of mentoring. Retrieved from https://www2/aston.ac.uk/current-students/getinvolved/mentoring-at-aston-university/peermentoring/benefits-of-mentoring on 24th November 2020.

Ayodeji, I. O. \& Adebayo, L. F. (2015). Role of mentorship in business development in Nigeria. Global Journal of Humanity and Management, 3(3), 17 - 38.

Azman, I., Muhammad, M. A. \& Sebastian, K. F. (2009). Mentoring program and its impact on individual's advancement in the 
Malaysian context. Journal of Industrial Engineering and Management, 2(3), 592 - 615.

Bailey, R. (2019). What is gender bias in the workplace? Retrieved from: https://builtin.com/diversity-inclusion/gender-bias-inthe-workplace.

Ballet, K. \& Kelchetermans, G. (2009). Struggling with workload: Primary teachers' experience of intensification. Teaching and Teacher Education, 25(8), 1150 - 1157.

Barab, S. A., Hay, K. E., Barnett, M. \& Squire, K. (2001). Constructing virtual worlds: Tracing the historical development of learner practices. Cognition and instruction, 19(1), 47-94.

Cartwright, M. (2012). Odysseus, Ancient History Encyclopedia.

Retrieved on 2 May, 2018 from

https://www.ancient.eu/odysseus.

Cheng, E. (2012). Knowledge strategies for enhancing school learning capacity. International Journal of Educational Management. 26(6) 577-592.

Cheng, E. C. K. (2011). Cultivating communities of practice via learning study for enhancing teacher learning. Global Learn, 1138-1152.

Collins, A., Brown, J. S. \& Newman, S. E. (1987). Cognitive apprenticeship: Teaching the craft of reading, writing and mathematics. (Technical Report No. 403). BBN laboratories, Cambridge, MA. Centre for the study of reading, University of Illinois.

Dabiri, M. M. \& Olorunleke, G. K. (2006). Implementation of mentoring programmes in Nigerian post primary schools. Advances in Management, 5(1), 132-140.

Ekechukwu, R. O. \& Horsfall, M. N. (2015). Academic mentoring in higher education: A strategy to quality assurance in teacher education in Nigeria. European Journal of Research and reflection in Educational Sciences, 3(2), 37 - 45.

Elegbuanya, A. (2012). Effects of coaching and mentoring on succession plan in organizations: A study of JUHEL Nigeria limited, Enugu state. (Unpublished M.B.A project presented to 
the Department of Management, Faculty of Business Administration, University of Nigeria, Enugu campus).

Gabriel, A. S., Butts, M. M., Yuan, Z., Rosen, R. L. \& Sliter, M. T. (2018). Further understanding incivility in the workplace: The effects of gender, agency, and communion. Journal of Applied Psychology, 103(4), 362.

Hassan, A. I., Baharom, M. N. \& Mutalib, R. A. (2017). Social capital and career advancement of female academic staff in Nigerian universities. Journal of Management Development, 36(4), 525541.

Hirsch, S. E., Lloyd, J. W. \& Kennedy, M. J. (2019). Professional Development in Practice: Improving Novice Teachers' Use of Universal Classroom Management. The Elementary School Journal, 12O(1), 61-87.

Hobson, A. J., Maxwell, B., Stevens, A., Doyle, K. \& Malderez, A. (2015). Mentoring and coaching for teachers in the further education and skills sector in England. Nottingham: Department for children, schools and families.

Holland, E. (2018). Mentoring communities of practice: what's in it for the mentor? International Journal of Mentoring and Coaching in Education, 7(2), 110-126.

Hoy, A. W. \& Spero, R. B. (2005). Changes in teacher efficacy during the early years of teaching: A Comparison on four Measures Teacher and Teacher Education, 21(4), 343 - 356.

Inzer, L. D. \& Crawford, C. B. (2005). A review of formal and informal mentoring: processes, problems and designs. Journal of Leadership Education, 4(1), 31 - 50.

John chapter 14 verse 12 (1611). The Holy Bible. Authorized King James Version. Copyright 2003 by Thomas Nelson, Inc. www.ThomasNelson.com.

Kolade, O. G. (2015). Mentoring as a competency tool for the development of the university teaching staff - A case study of Adekunle Ajasin University Akungba Akoko. International Journal of Academic Research in Business and Social Sciences, 5(6), $277-288$. 
Kram, K. E. (1985). Mentoring at Work. Grenview, IL: Scott, Foresman.

Lambert, J. (2016). Cultural diversity as a mechanism for innovation: Workplace diversity and the absorptive capacity framework. Journal of Organizational Culture, Communications and Conflict, 20(1), 68.

Leidenfrost, B., Strassnig, B., Schutz, M., Carbon, C. \& Schabmann, A. (2014). The impact of peer mentoring on mentee academic performance: Is any mentoring style better than no mentoring at all? International Journal of Teaching and Learning in Higher Education, 26(1), 102 - 111.

Malhotra, N. K., Birks, D. F. \& Wills, P. A. (2013). Essentials of marketing research. Harlow: Pearson.

Maslow, A. (1954). Motivation and Personality. New York: Harper and Row.

Maxwell, J. C. (1998). The 21 Irrefutable Laws of Leadership. Nashville: Thomas Nelson, Inc.

Menges, C. (2016). Toward improving the effectiveness of formal mentoring programs: Matching by personality matters. Group \& Organization Management, 41(1), 98-129.

Moon, T. M. (2014). Mentoring the next generation for innovation in today's organization. Journal of Strategic Leadership, 5(1), 23 35.

Ndaguba, E., Ijeoma, E.O.C., Nebo, G.I., Chungag, A.C. \& Ndaguba, J.D. (2018). Assessing the effect of inadequate service provision on the quality of life of the poor: A focus on justice and education in Nigeria. Cogent Social Sciences, 4(1), 1526437.

Nielsen, K. \& Kvale, S. (1997). Current Issues of Apprenticeship. Journal of Nordic Educational Research, 17, 130 - 140.

Nnaji, E. S., Uko, E. S. \& Nwafor, I. A. (2015). Enhancing professional competence of newly employed lecturers through mentorship: A focus on universities in Cross River State. International Journal of Research in Arts and Social Sciences, 8(2), 236 - 246.

Noe, R. A. (1988). An investigation of the determinants of successful assigned mentoring relationships. Personal Psychology, 41, 457 $-479$. 
Ojokuku, R. M. \& Sajuyigbe, A. S. (2015). Impact of mentoring on career development of academics in Nigerian universities. International Journal of Contemporary Education Research, 4(5), $95-105$

Okurame, D. E. \& Balogun, S. K. (2005). Role of informal mentoring in the career success of first - line bank managers: A Nigerian case study. Development International, 10(617), 512 - 521.

Okurame, D. E. (2008). Mentoring in the Nigerian Academia: experiences and challenges. International Journal of Evidence Based Coaching and Mentoring, 6(2), 45 - 56.

Olasupo, G. (2011). How does mentoring work? In A. A. Olowu (Ed.). Mentoring: A key issue in human resource management (pp 114 - 121). Ile-Ife. The Ife center for psychological studies.

Olowookere, E. I. (2012). Dysfunctional mentoring in M.A. Oladeji (Ed.) current thoughts in education (pp. 179 - 197). Oyo Society for Promoting Research, Education and Academic Development (SREAD).

Omale, S. A., Oguche, D., Duru, C. E. \& Idodo, M. D. (2017). Impact of mentoring on staff retention through knowledge transfer. An empirical evaluation of four private universities in the North Central Zone of Nigeria. Global Journal of Human Resource Management, 5(2), 21 - 31.

Popoola, F., Adesopo, A. \& Ajayi, M. (2013). Establishing effective mentoring culture among professional university administrators in Nigeria. Public Administration Research, 2(2), 134.

Rao, V. S. P. (2010). Human Resource Management. New Delhi: Excel Books.

Rodriguez, Y. E. \& Sjostrom, B. R. (2000). Faculty of colour in teacher education: a multicultural approach to mentoring for retention, 2000 and beyond. A paper presented at the $52^{\text {nd }}$ annual meeting of the American Association of Colleges for Teacher Education, Chicago. February 26 - 29. ERIC, ED 440076.

Rothwell, W. (2005). Effective succession planning: Ensuring leadership continuity and building talent from within. New York: American Management Association. 
Sawiuk, R., Taylor, W. G., \& Groom, R. (2017). An analysis of the value of multiple mentors in formalised elite coach mentoring programmes. Physical Education and Sport Pedagogy, 22(4), 403-413.

Sola, M. A. (2018). Mentoring and its influence on career development of academic members of selected tertiary institutions in Oyo state, Nigeria. Asian Research Journal of Arts and Social Sciences, 6(1), 1-9.

Talukder, A. K. M., Vickers, M., \& Khan, A. (2018). Supervisor support and work-life balance. Personnel Review, 47(3), 727-744.

Tanoli, M. F. (2016). Impact of training and mentoring on employee performance - empirical analysis of public and private universities' staff members of Islamabad. Retrieved on May 30, 2018 from https://mpra.ub.muenchen.de/74956/

Tjan, A. K. (2017). What the best mentors do. Harvard Business Review, 2(27), 17.

Undiyaundeye, F. A., \& Basake, J. A. (2017). Mentoring and career development of academics in colleges of education in cross river state, Nigeria. European Journal of Multidisciplinary Studies, 4(4), $98-104$.

University of the People (2020). 7 benefits of mentoring programs in the workplace. Retrieved from www.uopeople.edu/blog/7benefits-of-mentoring-programs-in-the-workplace/ on $24^{\text {th }}$ November 2020.

Walters, W., Robinson, D. B. \& Walters, J. (2020). Mentoring as meaningful professional development. International Journal of Mentoring and Coaching in Education, 9(1), 21-36.

Wenger - Trayner, E., \& Wenger - Trayner, B. (2015). Introduction to communities of practice: A brief overview of the concept and its uses. Retrieved on June 1 from http://wengertrayner.com/introduction-to-communities-of-practice/

Zachary, L. J. (2000). The mentor's guide: Facilitating effective learning relationships. San Francisco CA: Jossey-Bass. 